\title{
Localized Disease
}

National Cancer Institute

\section{Source}

National Cancer Institute. Localized Disease. NCI Thesaurus. Code C36162.

A disease that is confined to a specific organ or tissue and has not spread to other anatomic sites. 